France

\section{Biotechnology company planned}

A French banking consortium intends to create a company called Transgène to develop commercial applications of genetic been finalised, the consortium, known as Paribas, is expecting initially to invest about $£ 8$ million in a five year programme of research.

In addition to its own laboratories, Transgène is likely to have close links with universities and government research institutes. Paribas are negotiating the financial and legal aspects of such links and are said to favour a scheme in which collaborating laboratories and institutes would be rewarded with shares in the company.

Negotiations appear to be complicated by the involvement of many of the French scientists with relevant expertise in a public sector organisation, G-3, set up over a year ago because of the lack of private investment in biotechnology. G-3 is financed and run chiefly by the Institut Pasteur and the Centre National de la Recherche Scientifique, with minor contributions from the Institut National de la Santé et de la Recherche Médicale and the Institut National de la Recherche Agronomique. It has a laboratory and about five scientific staff at the Institut Pasteur and will be spending about $£ 0.3$ million this year, much of it on the development of a vaccine against hepatitis $\mathbf{B}$.

A further complication may arise from the possible role of Institut Pasteur Production (IPP), the commercial arm of the institute. At first IPP had preferential that arrangement no longer exists. The future of IPP is currently unclear, following the breakdown of long and complex negotiations over a merger with two French pharmaceutical companies, l'Institut Merieux and Rhone-Poulenc; a possible merger with Sanofi, a subsidiary of the oil company Elf, is now being negotiated. To close the circle of negotiations, a report in Le Monde suggests that Sanofi is also considering joining Transgène.

Given the limited number and prior involvement in G-3 of French scientists with expertise in genetic techniques it is likely that Transgène will recruit internationally. It remains to be seen whether they will be able to attract such a large number of good candidates as has the Genevabased company of Biogen, which has just appointed the first director of its scientific laboratory (see below).

Meanwhile the UK National Enterprise Board continues to contemplate the creation of a publicly-owned biotechnology company. Although enthusiasm for the idea is said to be high within the NEB, hopes for an early decision have abated probably because of pressure to involve private industry in the proposed company.

- Julian Davies, Professor of Biochemistry at the University of Wisconsin, is to be the first director of Biogen's laboratory in Geneva. A British-born and -trained biochemist, Professor Davies is best known for his work on the mechanisms of bacterial resistance to antibiotics. engineering. Although plans have not yet

rights on any successful G-3 project, but

Peter Newmark

\section{United States}

\section{Solar Polar Mission threatened}

EUROPEAN space officials travelled hastily to Washington last week in an attempt to prevent the US Congress from killing the International Solar Polar Mission, a joint effort by US and European scientists to send two spacecraft in complementary orbits around the Sun.

The mission was originally scheduled for launch in 1983, jointly funded by the National Aeronautics and Space Administration and the European Space Agency. Last month, reflecting moves to balance the federal budget and find additional funds for the much-delayed space shuttle, NASA announced that the launch would be delayed until 1985 .

Now a Congressional Committee is recommending that the mission be abandoned. In passing NASA's request for further support for the space shuttle in the current financial year, a House Appropriations Subcommittee has suggested that $\$ 15$ million be cut from the ISPM's budget of $\$ 47$ million - and that the mission should be terminated.
Canada

\section{3 percent boost} for research

CANADA'S new liberal government has, as expected, endorsed the substantial growth in support for basic research promised by the previous conservative government shortly before it was defeated in the general election last February.

Mr John Roberts, the Minister of State for Science and Technology, announced last week that the Natural Sciences and Engineering Research Council (NSERC), the largest of the three research councils, will receive a $35 \%$ increase in its $1980 / 81$ budget over the current year. This will bring the research council's total budget to $\$ 162.6$ million.

The NSERC increase is precisely the figure announced by $\mathrm{Mr}$ Robert's predecessor, $\mathrm{Mr}$ Howard Grafftey, in January, and is based on a five-year plan which the research council submitted to the government last year. The Medical Research Council will have its budget increased by $17 \%$ to $\$ 8.2 .2$ million, and the Social Science and Humanities Research Council by $16 \%$ to $\$ 41.7$ million.

In announcing these budget increases to the Canadian Association of University Research Administrators, Mr Roberts also said that the liberal government remained committed to its goal of raising the amount of the gross national product devoted to R\&D from $0.9 \%$ to $1.5 \%$ by the mid 1980 s. However to keep in line with this will, he said, require the government to find an extra $\$ 30$ million for R \& D in 1980/81 over and above the total increases of $\$ 155$ million already announced.

Canadian scientists, who have criticised the decision of Prime Minister Pierre Trudeau not to emulate the conservatives by appointing a minister with special responsibility for science - Mr Roberts also holds the portfolio for mines and energy - have nevertheless been cheered by the announcement that promised that funding increases will be honoured.

The Canadian government is also expected to announce shortly that it is setting up a high-level committee to examine how Canada should pursue its involvement in the field of biotechnology.

A study that has been prepared by the Ministry of State for Science and Technology shows that although various research programmes are currently underway - ranging from research on the cloning of insulin genes to studies of nitrogen fixation - they are widely dispersed and often lacking in depth.

For example, although about 100 university scientists are currently involved in biotechnology research, they are divided between 22 universities. Similarly of over 33 firms in the field, only ten have more than one or two research workers involved.

David Dickson 